Dept. of Food Hygiene,

Animal Health Research Institute, Assiut Branch, Assiut

\title{
PUBLIC HEALTH ASSESSMENT OF LISTERIA SPECIES IN SOME MEAT AND CHICKEN PRODUCTS IN ASSIUT CITY
}

(With 3 Tables and One Figure)

By

\section{A.M. ABD EL-MALEK; SOHAILA FATHI HASSAN ALI; R. HASSANEIN*; M.A. MOHAMED** and K.I. ELSAYH***}

*: Dept. of Animal Hygiene and Zoonoses, Fac. Vet. Med., Assiut Univ. **: Dept. of Poultry Diseases, Fac. Vet. Med., Assiut Univ. ***: Dept. of Pediatric, Fac. of Medicine, Assiut Univ. Assiut 71526, Egypt (Received at 25/8/2009)
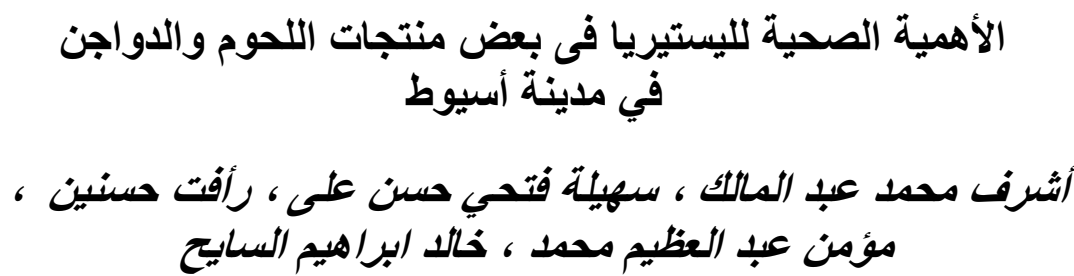

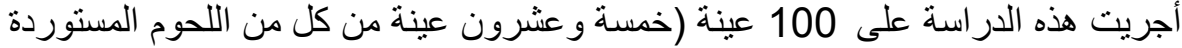

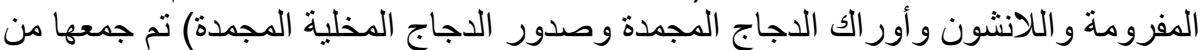

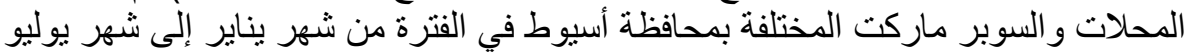

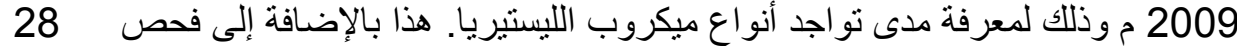

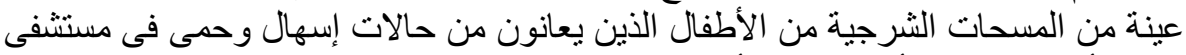

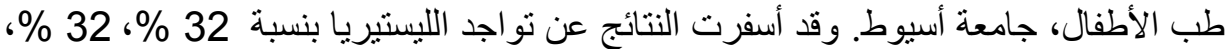

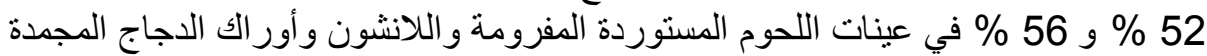

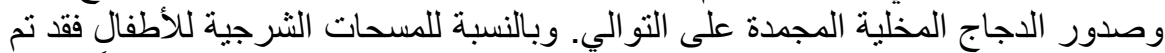
عزل الليستيريا بنسبة 7,14 \% الإنة تم اختيار 13 سلالة من الليستيريا المعزولة بناءاً على نتائج الاختبار ات الكيميائية ونتائجها الإيجابية فى إختبارى

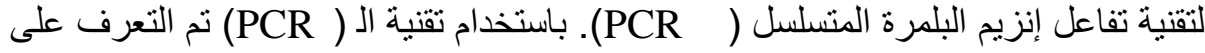

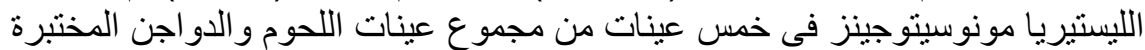

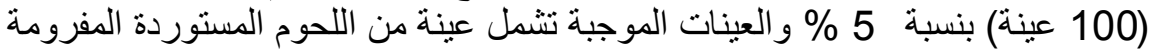

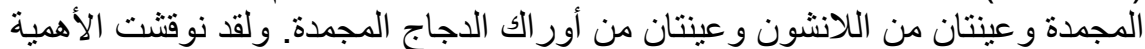
الصحية و الطرق الو اجب إتباعها للحد من تلوث منتجات التهات اللحوم و الدو اجن بهذا الميكروب. 
The present study was conducted for isolation of Listeria spp. in some selected meat and chicken products purchased from retail supermarkets in Assiut, Egypt. A total of 100 samples including 25 samples each of minced frozen beef, luncheon, frozen chicken legs and frozen chicken breast fillets were collected over a 7-month period between January and July 2009 and examined for the presence of Listeria spp. In addition, 28 stool cultures examined for Listeria spp. collected from hospitalized children resident in Assiut Pediatric University Hospital with history of diarrhea or fever. Out of the total 100 meat samples examined, Listeria spp. were detected in $8(32 \%)$ of minced frozen beef, $8(32 \%)$ of luncheon, $13(52 \%)$ of frozen chicken leg and $14(56 \%)$ of frozen chicken fillet samples examined, respectively. Regarding the examined stool cultures (28) from hospitalized children with underlying disease in Assiut University hospital, 2 (7.14\%) were found positive for Listeria spp. For identification of $L$. monocytogenes using polymerase chain reaction (PCR), two primers were selected based on the prfA (transcriptional activator of the virulence factor) gene for L. monocytogenes. 13 selected Listeria isolates displayed betahaemolysis on sheep blood agar and positive CAMP test were further identified using PCR. PCR results showed that L. monocytogenes were confirmed in one of minced imported frozen meat, two of luncheon samples and two of frozen chicken legs with the total incidence of 5 isolates $(5 \%)$ from the total 100 examined food samples. This study suggests the presence of a significant public health hazard linked to the consumption of these meat and chicken products sold in Assiut city contaminated with L. monocytogenes. The public health significance of this pathogen and sanitary measures were discussed.

Key words: Listeria spp, L. monocytogenes, minced beef, luncheon, chicken fillet, chicken legs, children stools, PCR..

\section{INTRODUCTION}

The marked increased of contamination in food industry specially meat and chicken products by pathogenic bacteria has raised a great concern of the public. Listeria spp. especially L. monocytogenes has been associated with a wide variety of food sources particularly meat and chicken (Endang et al., 2003).

Listeria spp. is ubiquitous bacteria widely distributed in the natural environment. The ubiquitous character of the bacteria inevitably 
results in contamination of numerous food products (Farber and Peterkin, 1991).

The genus Listeria includes 6 different species (L. monocytogenes, L. ivanovii, L. innocua, L. welshimeri, L. seegligeri and $L$. grayi). Both $L$. ivanovii and L. monocytogenes are pathogenic in mice, but only L. monocytogenes is consistently associated with human illness (Seafood Network Information Center, 2007).

Listeria spp. has been isolated from poultry, red meat and meat products in many countries around the world such as Yugoslavia (Buncic, 1991), Belgium (Uyttendaele et al., 1999), New Zealand (Hudson et al., 1992), Australia (Ibrahim and Mac Rae, 1991), and Japan (Ryu et al., 1992), although these foods have not been associated with documented outbreaks of human listeriosis. Detection of Listeria spp. in meat is of particular concern in terms of consumer safety, as these organisms are capable of growing on both raw and cooked meat at refrigeration temperatures (Walker et al., 1990).

In the past 25 years, L. monocytogenes has become increasingly important as a food-associated pathogen. Because of its high case fatality rate, listeriosis ranks among the most frequent causes of death due to food-borne illness. Also, L. monocytogenes infections are responsible for the highest hospitalisation rates (91\%) amongst known food-borne pathogens and have been linked to sporadic episodes and large outbreaks of human illness worldwide. The ability to persist in food-processing environments and multiply under refrigeration temperatures makes L. monocytogenes a significant threat to public health (Jemmi and Stephan, 2006).

Moreover, L. monocytogenes is an important food-borne pathogen that can cause septicemia, meningitis (or meningoencephalitis), encephalitis and gastroenteritis, particularly in children, the elderly and immunosuppressed individuals; it also causes miscarriage in pregnant women. The mortality rate can be as high as 30\% (Robinson et al., 2000; Churchill et al., 2006).

Unlike most other enteric pathogens, L. monocytogenes is notable for its ability to grow at refrigeration temperatures. This has considerable significance for food safety, as it means that chilling to $4^{\circ} \mathrm{C}$ cannot be relied upon to prevent the growth of the organism to dangerous levels (Pal et al., 2008). In addition, because of its ability to survive and proliferate at refrigeration temperature, L. monocytogenes may cause disease through frozen foods (Schillinger et al., 1991). Due to 
its ubiquitous character, L. monocytogenes easily enters the human food chain and may multiply rapidly (Farber and Peterkin, 1991).

The standard microbiological methods for identification of Listeria spp. are laborious and time consuming requiring a minimum of five days to recognize Listeria spp. and about 10 days to identify L. monocytogenes by confirmation tests (Amagliani et al., 2007) while rapid response should be carried out in case of confirmation since it is of principal importance to ensure the safety of foods.

In the few past years, progressing in biotechnology has resulted in the development of rapid methods that reduce the analysis time and offer great sensitivity and specificity in the detection of pathogens. Among these, PCR has been increasingly used for the rapid, sensitive and specific detection of food-borne pathogens (Norton, 2000).

Therefore, the goal of this study was to determine the incidence of Listeria spp. and L. monocytogenes in minced frozen beef, luncheon, and frozen chicken meats as well as in children stools collected from hospitalized children resident in Pediatric University Hospital in Assiut, Egypt.

\section{MATERIALS and METHODS}

\section{Collection of samples:}

A total of 100 random samples of meat and chicken products $(25$ samples each of minced frozen beef, luncheon, frozen chicken legs, and frozen chicken breast fillets without skin) were collected from different retail supermarkets and groceries in Assiut city. The collected samples were transferred directly to the laboratory in an ice box for bacteriological examination.

\section{Preparation of samples:}

At the laboratory, frozen samples were thawed by overnight refrigeration. Each sample was aseptically and carefully freed from its casings and mixed thoroughly in sterile mortar.

\section{Children samples:}

To identify the occurrence of Listeria infections in hospitalized children in Assiut, the cases-control study was conducted. These cases addmitted in Pediatric Univ. Hospital; Assiut Univ., with diarrhea or fever between January and July 2009. A stool culture examined for Listeria spp. and the parents of the cases were interviewed, using a standardized questionnaire including addressing the family's consumption of, and purchasing and preparation conditions for, various 
foods such as poultry and beef, and their contacts with people having diarrhea.

\section{Isolation of listeria spp. (FAO, 1992):}

\section{Enrichment procedures}

The initial procedure of isolation involves the use of Listeria selective enrichment broth (LSEB) to enhance the growth of Listeria spp. LSEB base consists of trypticase soy broth with $0.6 \%$ yeast extract supplemented with Listeria selective supplement (HiMedia laboratories) which contains acriflavin-HCL $(15 \mathrm{mg} / \mathrm{L})$, nalidixic acid $(40 \mathrm{mg} / \mathrm{L})$ and cycloheximide $(50 \mathrm{mg} / \mathrm{L})$. Ten grams of samples as well as swabs from human stools were aseptically added to $90 \mathrm{ml}$ LSEB and mixed thoroughly. All the primary enrichment broths were incubated at $37^{\circ} \mathrm{C}$ and $30^{\circ} \mathrm{C}$ for $24-48 \mathrm{~h}$.

\section{Selective plating}

Following the enrichment procedure, a loopful of the homogenate was streaked onto Listeria selective agar base (Hi Media laboratories) and Oxford - Listeria Selective Agar and the plates were incubated at $35^{\circ} \mathrm{C}$ for $24-48 \mathrm{~h}$.

Confirmation: Colonies suspected to be Listeria were characterized using Gram stain; catalase reaction; umbrella-shaped motility pattern by using motility test medium; haemolysis on sheep blood agar; fermentation of mannitol, rhamnose and xylose and CAMP test performed according to Bergey's Manual of Systematic Bacteriology (Seeliger and Jones, 1987).

\section{Genomic DNA Extraction}

For each Listeria strain, a 10-ml culture was grown to mid-log phase in Tryptose Soya (TSY) broth, and $1 \mathrm{ml}$ of cells was pelleted by centrifugation $(13.000 \times \mathrm{g}$ for $5 \mathrm{~min})$. The cell pellets were resuspended in $1 \mathrm{ml}$ of sterile water. The resuspended cells were re-centrifuged at $12.500 \times \mathrm{g}$ for $15 \mathrm{~min}$. The pelleted cells were then used for DNA extraction.

Genomic DNA from suspected Listeria strains was extracted using the Wizard genomic DNA purification kit (Promega, USA) as recommended by the manufactures. Protocol for Gram positive bacteria, cellular lyses was carried out by enzymatic fragment with lysozyme. DNA samples were stored at $-20{ }^{\circ} \mathrm{C}$ until use.

\section{PCR identification of Listeria monocytogenes.}

For L. monocytogenes PCR identification, two primers were selected based on the prfA (transcriptional activator of the virulence 
factor) gene for L. monocytogenes as mentioned by (Germini et al., 2009). Primer sequences used in the PCR are listed in Table 1.

Table 1: Oligonucleotide sequences used for identification of Listeria monocytogenes by PCR.

\begin{tabular}{|c|c|c|c|}
\hline $\begin{array}{c}\text { Target } \\
\text { gene }\end{array}$ & Primer sequence (5'-3') & $\begin{array}{c}\text { Amplified } \\
\text { fragment length }\end{array}$ & Reference \\
\hline prfA gene & $\begin{array}{c}\text { LIS-F: TCA TCG ACG GCA ACC TCG G } \\
\text { LIS-R: TGA GCA ACG TAT CCT CCA GAG T }\end{array}$ & 217 bp & $\begin{array}{c}\text { Germini } \text { et al. } \\
(2009)\end{array}$ \\
\hline
\end{tabular}

All PCR reactions were performed in a final volume of $25 \mu 1$ using $2 \mu \mathrm{l}$ of extracted DNA as template. Each reaction mixture contained $12.5 \mu \mathrm{l}$ GoTaq ${ }^{\circledR}$ Green Master Mix (Promega, M7122) $1 \mu 1$ of $500 \rho \mathrm{M}$ forward primer (LIS-F); $1 \mu \mathrm{l}$ of $500 \mathrm{pM}$ reverse primer (LIS-R) and $8 \mu \mathrm{l}$ of Ultra-Pure DNase/RNase-Free Distilled Water (Gibco, Grand Island, NY, USA).

The amplification profile was as follows: pre incubation at $95{ }^{\circ} \mathrm{C}$ for $5 \mathrm{~min}$; 40 cycles consisting of dsDNA denaturation at $95{ }^{\circ} \mathrm{C}$ for $30 \mathrm{~s}$, primer annealing at $54^{\circ} \mathrm{C}$ for $30 \mathrm{~s}$, primer extension at $72{ }^{\circ} \mathrm{C}$ for $30 \mathrm{~s}$; final elongation at $72{ }^{\circ} \mathrm{C}$ for $5 \mathrm{~min}$. Reactions were thermally cycled in a Techne Cyclogene.

Gel Electrophoresis: All amplification products were resolved in 1\% agarose gel, stained with ethidium bromide, detected under a shortwavelength UV light source, and photographed with EDVOTEK Gel documentation system. The 1-KB plus DNA Ladder (Invitrogen) was used as molecular size marker.

\section{RESULTS}

Table 2: Isolation rate of Listeria spp. from different food and children samples

\begin{tabular}{|c|c|c|c|}
\hline Type of samples & \multirow{2}{*}{$\begin{array}{c}\text { No. of examined } \\
\text { samples }\end{array}$} & No. & $\%$ \\
\cline { 3 - 4 } & 25 & 8 & 32 \\
\hline $\begin{array}{c}\text { Minced frozen } \\
\text { meats }\end{array}$ & 25 & 8 & 32 \\
\hline Luncheon & 25 & 11 & 44 \\
\hline $\begin{array}{c}\text { Chicken frozen } \\
\text { fillets }\end{array}$ & 25 & 14 & 56 \\
\hline $\begin{array}{c}\text { Chicken frozen } \\
\text { legs }\end{array}$ & 28 & 2 & 7.14 \\
\hline Children stools & 128 & 43 & 33.59 \\
\hline Total & & &
\end{tabular}


Table 3: Incidence of Listeria spp. in meat and chicken products as well as in children stools.

\begin{tabular}{|c|c|c|c|c|c|c|c|c|c|c|c|c|c|c|}
\hline \multirow{2}{*}{$\begin{array}{l}\text { Listeria } \\
\text { spp } \\
\text { Samples }\end{array}$} & \multicolumn{2}{|c|}{\begin{tabular}{|c|}
$L$. \\
monocyto \\
genes \\
\end{tabular}} & \multicolumn{2}{|c|}{$\begin{array}{c}\text { L. } \\
\text { ivanovii }\end{array}$} & \multicolumn{2}{|c|}{$\begin{array}{c}\text { L. } \\
\text { innocua }\end{array}$} & \multicolumn{2}{|c|}{$\begin{array}{c}\text { L. } \\
\text { welshimeri }\end{array}$} & \multicolumn{2}{|c|}{$\begin{array}{l}\text { L. } \\
\text { seeligeri }\end{array}$} & \multicolumn{2}{|c|}{ L. grayi } & \multicolumn{2}{|c|}{$\begin{array}{c}\text { L. } \\
\text { murrayi }\end{array}$} \\
\hline & No. & $\%$ & No. & $\%$ & No. & $\%$ & No. & $\%$ & No. & $\%$ & No. & $\%$ & No. & $\%$ \\
\hline Minced meat & 1 & 4 & - & - & 7 & 28 & - & - & - & - & - & - & - & - \\
\hline Luncheon & 2 & 8 & 1 & 4 & - & - & 2 & 8 & 2 & 8 & 1 & 4 & - & - \\
\hline $\begin{array}{c}\text { Frozen } \\
\text { chicken fillet }\end{array}$ & - & - & 3 & 12 & 2 & 8 & 2 & 8 & - & - & 4 & 16 & - & - \\
\hline $\begin{array}{c}\text { Frozen chicken } \\
\text { leg } \\
\end{array}$ & 2 & 8 & 3 & 12 & 3 & 12 & 3 & 12 & - & - & 2 & 8 & 1 & 4 \\
\hline Children stools & - & - & - & - & - & - & - & - & 1 & 3.8 & 1 & 3.8 & - & - \\
\hline Total & 5 & 20 & 7 & 28 & 12 & 48 & 7 & 28 & 3 & 11.8 & 8 & 31.8 & 1 & 4 \\
\hline
\end{tabular}

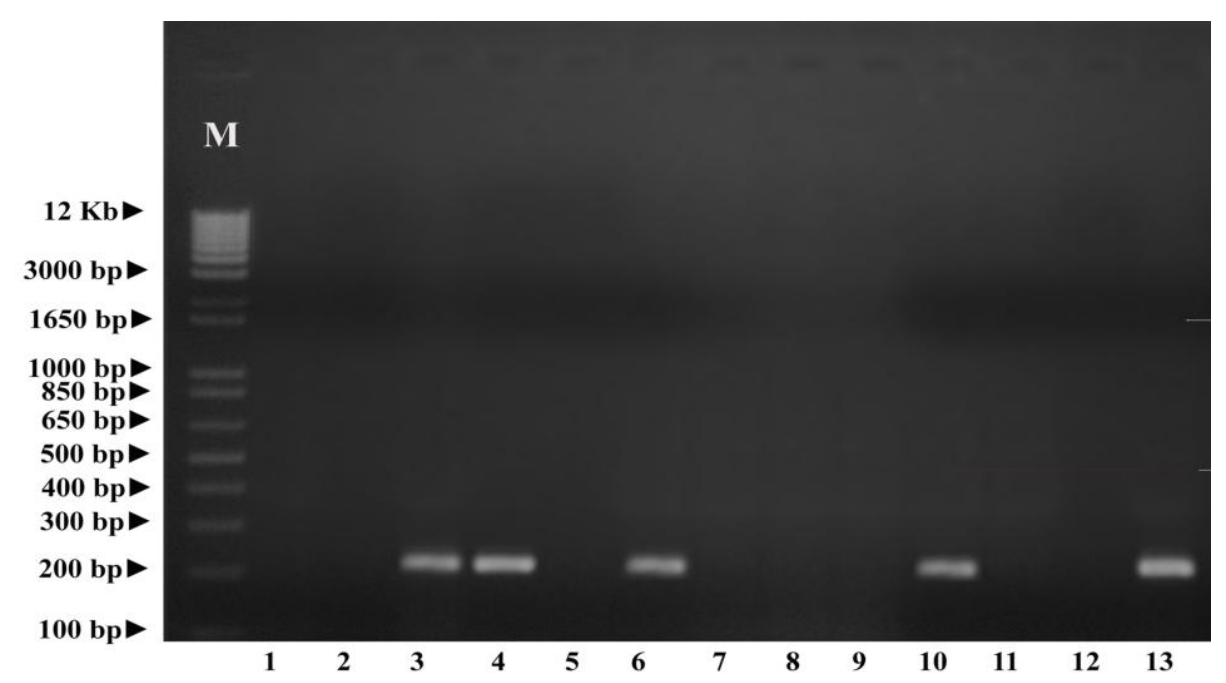

Fig. 1: Agarose gel electrophoresis of PCR products from Listeria monocytogenes isolates from examined samples: Lan M, DNA size marker (1-KB Plus DNA Ladder); lane 1, (L 1), lane 2, (L 4); lane 3, (L 3), lane 4, (L 18); lane 5, (F 9); lane 6, (Lu 9); Lan7, (Lu 7); Lan 8, (Lu 13); Lan 9 (F 14); Lan 10, (M 16), Lan 11, (L 11); Lan 12, (H 26); Lan 13, (Lu 18).

L: chicken leg isolate,

F: chicken fillet isolate,

$\mathrm{Lu}$ : luncheon isolate,

M: minced meat isolate,

$\mathrm{H}$ : Human stool isolate. 


\section{DISCUSSION}

Meat and chicken products have been frequently contaminated with L. monocytogenes and may serve as vehicle of other pathogenic organisms. The frequent occurrence of L. monocytogenes in meat and chicken may pose a potential risk for consumers (Mahmood et al., 2003). Human infections primarily result from eating contaminated food and may lead to serious and potentially life-threatening listeriosis (Posfay-Barbe and Wald, 2004).

Out of the 100 meat and chicken product samples examined, 41 (41\%) isolates of Listeria spp. were recovered. Of these, 13 isolates displayed beta-haemolysis on sheep blood agar and positive CAMP test and identified using PCR.

The wide application of nucleic acid amplification techniques and the increasing industrial interest toward rapid methods has led to the development and application of PCR based methods for the detection of microbial pathogens in food (Germini et al., 2009).

Analyzing the PCR profiles, 5 out of 13 Listeria isolated strains showed one amplified product (217 bp), (Fig. 1) which is specific for L. monocytogenes. Thus, L. monocytogenes were confirmed in one of minced imported frozen meat examined, two of luncheon samples and two of frozen chicken legs with the total incidence of 5 isolates (5\%) from the total 100 examined samples (Table 3 and Figure 1). This results suggests the presence of a significant public health hazard linked to the consumption of these meat and chicken products sold in Assiut city contaminated with L. monocytogenes.

The percentage of culture positivity of L. monocytogenes in meat and chicken products in the present study is in agreement with the reported incidences in other countries such as 5.1\% in Ethiopia (Molla et al., 2004), $4.9 \%$ in Belgian meat products (Uyttendaele, 1999) and $3.6 \%$ in processed meat products in Chile (Cordano and Rocourt, 2001).

When several studies in different countries are compared, L. monocytogenes isolation rates seem to vary significantly. This wide variation may be explained in terms of geographic location, isolation methods and kinds of media employed (Akpolat et al., 2004).

Concerning minced imported frozen meat examined in our study, Listeria spp. were isolated from 8 (32\%) of 25 examined samples. L. monocytogenes occurred in one (4\%) and L. innocua in 7 (28\%) of the examined samples, respectively (Tables2 \& 3). Similarly, the isolation rate of $L$. monocytogenes in minced beef samples was $5 \%$ in a study in 
Turkey conducted by Akpolat et al. (2004). Nearly, similar results were obtained by other researchers such as Abd El-Aziz (2004) (6\%) and Marinsek and Grebenc (2002) who isolated L. monocytogenes from 3 of the minced meat samples $(6.81 \%)$.

On the other hand, higher records were reported by several investigators as Hassan et al. (2001) who found Listeria species in 17 (73.9\%) of 23 samples of imported frozen beef in Malaysia and Donald et al. (1991) who reported that imported frozen beef examined harbored seven Listeria spp: 15 L. monocytogenes, 18 L. ivanovii, 32 L. innocua, 2 L. seeligeri, 11 L. grayi, 7 L. murrayi, and 13 L. welshimeri isolates, respectively in Canada. Also, Inoue et al. (2000) isolated L. monocytogenes from $12.2 \%$ of the minced meat samples in Japan and Buncic (1991) detected L. monocytogenes in $69 \%$ of minced meat samples in Yugoslavia.

It is interesting to note that $L$. innocua was isolated predominantly among Listeria spp. in minced frozen meat in this study (Table 3). This finding is in agreement with other studies where L. innocua was the most common species in raw and cooked meats, while other Listeria spp. were less frequently (Choi et al., 2001; De Simon et al., 1992). As similar, L. innocua was the most predominantly isolated spp. from a variety of meat samples. It was detected in $83.3 \%$ of the raw minced meat, $57.6 \%$ of the raw chicken meat, $63.1 \%$ of the raw beef, $9.6 \%$ of the cooked red meat and $10.7 \%$ of the cooked chicken samples (Yucel et al., 2005).

Furthermore, detection of L. monocytogenes in foods can be difficult as these bacteria are normally found in very low numbers in the presence of a heterogenous microflora. The most frequent Listeria isolates from food are L. monocytogenes and L. innocua. Several studies have demonstrated that L. innocua is found in food more frequently than L. monocytogenes (Walsh et al., 1998). The reasons for the higher frequency of recovery of $L$. innocua remain unclear yet. However, this may result from either a naturally higher prevalence or from preferential selection of L. innocua during laboratory detection procedures (Gnanou Besse et al., 2005).

Contamination of the meat with $L$. monocytogenes generally occurs after the slaughter and may come from the skin of the animals, the hands of the workers, the equipment and the tools used (Marinsek and Grebenc, 2002).

Regarding luncheon samples as shown in Table (3), Listeria spp. isolated were L. monocytogenes comprising (8\%0) of the samples, 
followed by L. welshimeri (8\%), L. seeligeri (8\%), L. ivanovii (4\%) and L. grayi (4\%). In this research, L. monocytogenes was determined in 2 (8\%) samples of luncheon meat. Lower incidence was obtained by Gombas et al. (2003) who found L. monocytogenes in 0.89 of luncheon meat. In contrast, L. monocytogenes could not be isolated from luncheon samples as reported by Elgazzar and Sallam, (1997); Mohamed and Ali, (1999); Saad et al. (2001).

Cross-contamination, which can occur within the environment of food-processing equipment, is considered to be a possible source of Listeria contamination in processed meat such as luncheon. L. monocytogenes is able to attach to and survive on various working contact surfaces (Borucki, 2003). One reason may be its ability to form biofilms (Wong, 1998).

Furthermore, during further transformation processes of raw meat into meat products L. monocytogenes can be introduced, where the amount depends on the extent of cross-contamination, personal and general hygienic measures and the process parameters (Glass and Doyle, 1989).

In addition, minced/chopped meat products as luncheon, by their nature, undergo extensive processing and handling during their production. This leads to greater opportunities for L. monocytogenes contamination (Tompkin et al., 1992; Uyttendaele, 1997).

The ability of L. monocytogenes to multiply at refrigeration temperatures could be considered of a significance in food intended for consumption without further cooking as luncheon meat and foods which have received cooking presumed sufficient to eliminate Listeria, but nevertheless intended be received further cooking prior to consumption where the potential competitive microflora has been largely eliminated and thus even low numbers could pose a potential hazard if proper storage conditions are not adhered to (Schuchat et al., 1992).

Frozen chicken breast fillet examined harbored variable rates of four Listeria species: 3 (12\%) L. ivanovii, 2 (8\%) L. innocua, 4 (16\%) L. grayi and $2(8 \%)$ L. welshimeri isolates, respectively (Table 3).

In this study, L. monocytogenes was not isolated from any of the 25 samples of frozen chicken breast fillet examined. On the other hand, L. monocytogenes was determined in 9 samples of mechanicallydeboned chicken meat (15.78\%) (Marinsek and Grebenc, 2002). Also, Hindy (2006) isolated listeria spp. from $28 \%$ of chicken fillet, from which $8 \%$ were L. monocytogenes. 
It is also important to comment that the presence of any Listeria spp. may be indicative of poor hygiene and cross-contamination scenarios which could favour the persistence of $L$. monocytogenes (Azevedo et al., 2005).

Of the 25 frozen chicken legs samples examined, 14 (56\%) were found to be contaminated with Listeria species (Table 2). L. monocytogenes could be detected in $2(8 \%)$ samples of chicken legs examined in the present study. This obtained result was in agreement with other reports as in the study by Arslan et al. (1999), who mentioned that L. monocytogenes was found at $15 \%, 10 \%$ and $5 \%$ in wing, leg and washing water, respectively, of 20 chickens. In the contrary, several studies showed that the rates of L. monocytogenes varied between $23 \%$ and 60\% (Pini and Gilbert, 1988; Skovgaard and Morgen, 1988).

Poultry can harbour L. monocytogenes in their intestinal tract and as such are a potential source of contamination (Capita et al., 2002). Therefore, higher incidence of Listeria in chicken meat products could be attributed to contamination caused by chopping board, mincing machine, knives, cleaning cloth, other working surfaces and more human contact (Lowry and Tiong, 1985).

Moreover, L. monocytogenes has been strongly implicated particularly in the contamination of foods stored at low temperatures. Storage of such products under such low temperature conditions may allow the growth of significant numbers of these organisms leading to food-borne illnesses among consumers (Walker et al., 1990; Beumer et al., 1996).

Concerning the examined 28 stool cultures from hospitalized children with underlying disease in Assiut Univ. hospital, 2 (7.14\%) were found positive for Listeria species from which one L. seeligeri and one L. grayi.

In order to minimize human listeriosis, foods should be cooked to an internal temperature of $70{ }^{\circ} \mathrm{C}$ for more than 20 minutes to ensure destruction of L. monocytogenes. Reheat cooked food thoroughly $\left(70{ }^{\circ} \mathrm{C}\right)$, immediate aseptic packaging of the finished product to avoid post processing environmental contamination. Proper cold storage of meat and meat products (freezing $-18^{\circ} \mathrm{C}$ ) and proper personal hygiene of food handlers is advisable (Mahmood et al., 2003).

It was significantly important for public health to detect Listeria spp., and particularly L. monocytogenes, in meat products sold in Assiut, since consumers are frequently exposed to these products. Therefore, 
meat and meat products must be thoroughly cooked or grilled before consumption so L. monocytogenes is likely to be eliminated.

In conclusion, this study has demonstrated the presence and distribution of L. monocytogenes and other Listeria spp. in a variety of meat and chicken products in Assiut city. The study also suggests the need for improved food safety through the implementation of hygienic measures at all levels from production to consumption.

\section{REFERENCES}

Abd El-Aziz, Doaa, M. (2004): Microbiological and chemical hazards of some meat products. M. V. Sc. Thesis. Fac. Vet. Medicine, Assiut University, Assiut, Egypt.

Akpolat, N.O.; Elci, S.; Atmaca, S. and Gül, K. (2004): Listeria monocytogenes in products of animal origin in Turkey. Vet. Res. Commun., 28(7):561-567.

Amagliani, G.; Giammarini, C.; Omiccioli, E.; Brandi, G. and Magnani, M. (2007): Detection of Listeria monocytogenes using a commercial PCR kit and different DNA extraction methods. Food Control, 18: 1137-1142.

Arslan, A.; Goniilalan, Z.; Din oglu, A.H. and Kok, E. (1999): Investigation of Listeria species in chicken body parts and samples of water used for washing carcasses. Turkish Journal of Veterinary and Animal Sciences, 23: 305-308

Azevedo, I.; Regalo, M.; Mena, C.; Almeida, G. et al. (2005): Incidence of Listeria spp. in domestic refrigerators in Portugal. Food Control, 16: 121-124.

Beumer, R.R.; Te Giffel, M.C.; De Boer, E. and Rombous, F.M. (1996): Growth of Listeria monocytogenes on sliced cooked meat products. Food Microbiol., 13: 333-340.

Borucki, M.K.; Peppin, J.D.; White, D.; Loge, F. and Call D.R. (2003): Variation in biofilm formation among strains of Listeria monocytogenes . Appl. Environ. Microbiol., 69: 7336-7342.

Buncic, S. (1991): The incidence of Listeria monocytogenes in slaughtered animals, in meat, and in meat products in Yugoslavia. Int. J. Food Microbiol., 12: 173-180.

Capita, R.; Alonso-Calleja, C.; Mereghetti, L.; Moreno, B. and Del Camino Garcia-Fernandez, M. (2002): Evaluation of the international phage typing set and some experimental phages 
for typing of Listeria monocytogenes from poultry in Spain. J. Appl. Microbiol., 92: 90-96.

Choi, Y.; Cho, S.; Park, B.; Chung, D. and Oh, D. (2001): Incidence and characterization of Listeria spp. from foods available in Korea. J. Food Prot., 64: 554-558.

Churchill, R.L.T.; Lee, H. and Hall, Ch. (2006): Detection of Listeria monocytogenes and the toxin listeriolysin $\mathrm{O}$ in food. $\mathrm{J}$. Microbiol. Methods, 64: 141-170.

Cordano, A.M. and Rocourt, J. (2001): Occurrence of Listeria monocytogenes in food in Chile. Int. J. Food Microbiol., 70: 175-178.

De Simon, M.; Tarrago, C. and Ferrer, M.D. (1992): Incidence of Listeria monocytogenes in fresh foods in Barcelona (Spain). Int. J. Food Microbiol.,16: 153-156.

Donald, W.W.; Jeffrey, M.F.A.; Ricardo, C., et al. (1991): A Canadian comparative study of modified versions of the FDA and USDA methods for the detection of Listeria monocytogenes. J. Food Prot., 54: 669-676.

Elgazzar, M.M.M. and Sallam, Kh.I.A. (1997): Occurrence of Listeria monocytogenes and other listeria species in meat products. Alexandria Journal of Veterinary Science 13, 4: 415- 422.

Endang, P.; Radu, S.; Ismail, A.; Kgueen, C.Y. and Maurice, L. (2003): Characterization of Listeria monocytogenes isolated from chicken meat: Evidence of Conjugal transfer of Plasmidmediated Resistance to Antibiotic. J. Animal Vet. Adv., 2: 237-246.

FAO, (1992): Listeria. In: Andrew, W. (ed), 4.Rev .1. Manual of food quality control. Microbiological analysis. Chapter 11, P 119-130. Rome, 1992.

Farber, J.M and Peterkin, P.I. (1991): Listeria monocytogenes, a foodborne pathogen. Microbiol. Rev., 55: 476-511.

Germini, A.; Masola, A.; Carnevali, P. and Marchelli, R. (2009): Simultaneous detection of Escherichia coli O175:H7, Salmonella spp., and Listeria monocytogenes by multiplex PCR, Food Control, 20(8): 733-738

Glass, K.A. and Doyle, M.P. (1989): Fate and thermal inactivation of Listeria monocytogenes in processed meat products during refrigerated storage. Appl. Environ. Microbiol., 55: $1565-1569$. 
Gnanou Besse, N.; Audinet, N.; Kerouanton, A.; Colin, P. and Kalmokoff, M. (2005): Evolution of Listeria populations in food samples undergoing enrichment culturing. Int. J. Food Microbiol., 104: 123-134.

Gombas, D.E.; Chen, Y.; Clavero, R.S. and Virginia, N. (2003): Survey of Listeria monocytogenes in Ready-to-Eat Foods. J. Food Prot., 66: 556-569.

Hassan, Z.; Endang Purwati, E.; Abdul Rahim, S.R. and Rusul, G. (2001): Prevalence of Listeria Spp and Listeria monocytogenes in meat and fermented fish in Malaysia. Southeast Asian J. Trop. Med. Public Health, 32, 2, June 2001.

Hindy, B.A. (2006): Further studies on listeria organisms. Ph. D., Thesis, Fac. Vet. Med., Cairo University, Egypt.

Hudson, J.A.; Mott, S.J.; Delacy, K.M. and Edridge, A.L. (1992): Incidence and coincidence of Listeria spp. motile aeromonads and Yersinia enterocolitica on ready-to-eat flesh foods. Int. J. Food Microbiol., 16: 99-108.

Ibrahim, A. and Mac Rae, I.C. (1991): Incidence of Aeromonas and Listeria spp. in red meat and milk samples in Brisbane, Australia. Int. J. Food Microbiol., 12: 263-270.

Inoue, S.; Nakama, A. and Arai, Y., et al. (2000): Prevalence and contamination levels of Listeria monocytogenes in retails foods in Japan. Int. J. Food Microbiol., 59: 73-77.

Jemmi, T. and Stephan, R. (2006): Listeria monocytogenes: food-borne pathogen and hygiene indicator. Rev. sci. tech. Off. int. Epiz., 25 (2): 571-580.

Lowry, P.D. and Tiong, I. (1985): The incidence of Listeria monocytogenes in meat and meat products factors affecting distribution. In Proc. $34^{\text {th }}$ Int. Congress Meat Sci. Tec. Part. B: 528-530.

Mahmood, M.S.; Ahmed, A.N. and Hussain, I. (2003): Prevalence of Listeria monocytogenes in Poultry Meat, Poultry Meat Products and Other Related Inanimates at Faisalabad. Pakistan Journal of Nutrition, 2 (6): 346-349.

Marinsek, J. and Grebenc, S. (2002): Listeria monocytogenes in minced meat and thermally untreated meat products in Slovenia. Slovenian Veterinary Research, 39 (2): 131-136.

Mohamed, Amal, A. and Ali, M.M. (1999): Incidence of Listeria monocytogenes in some meat products and poultry. Assiut Vet. Med. J. 40, 80: 581-584. 
Molla, B.; Yilma, R. and Alemayehu, D. (2004): Listeria monocytogenes and other Listeria species in retail meat and milk products in Addis Ababa, Ethiopia. Ethiop. J. Health Dev., 18 (3).

Norton, D. (2002): Polymerase chain reaction-based methods for detection of Listeria monocytogenes: toward real time screening for food and environment samples. J. AOAC Int., 85: 505-515.

Pal, A.; Labuza, T.P. and Diez-Gonzalez, F. (2008): Comparison of primary predictive models to study the growth of Listeria monocytogenes at low temperatures in liquid cultures and selection of fastest growing ribotypes in meat and turkey product slurries. Food Microbiology, 25: 460-470.

Pini, P.N. and Gilbert, R.I. (1988): The occurrence in the UK of Listeria species in raw chickens and soft cheeses. Int. J. Food Microbiol., 6: 317-326.

Posfay-Barbe, K.M. and Wald, E.R. (2004): Listeriosis. Pediatr. Res., 25: 151-159.

Robinson, R.K.; Batt, C.A. and Patel, P.D. (editors) (2000): Encyclopedia of Food Microbiology. San Diego, CA: Academic Press.

Ryu, C.H.; Igimi, S.; Inoue, S. and Kumagai, S. (1992): The incidence of Listeria species in retail foods in Japan. Int. J. Food Microbiol., 16: 157-160.

Saad, M.S.; Ibrahim, Hammat, M.; Niazi, Zienab, M. and El-Lawandy, Hanan, M. (2001): Prevalence of listeria species in meat and meat products. Vet. Med. J., Giza, 49, 4: 543-552.

Schillinger, U.; Kaya, M. and Lucke, F.K. (1991): Behaviour of Listeria monocytogenes in meat and its control by a bacteriocin producing strain of Lactobacillus. J. Appl. Bacteriol., 70: 473-478.

Schuchat, A.; Deaver, K.A.; Wenger, J.D.; Plikaytis, B.D.; Rengold, A.L. and Broome and the Listeria Study Group, C. (1992): Role of foods in sporadic listeriosis. J. Am. Med. Assoc., 276: 2041-2045.

Seafood Network Information Center (2007): Compendium of Fish and Fishery Product Processes, Hazards, and Controls Chapter 15: Listeria monocytogenes Retrieved November 7, 2008, from http://seafood.ucdavis.edu/haccp/compendium/chapt15.htm. 
Seeliger, H.P.R. and Jones, D. (1987): Listeria. In: Holt, J.G. (Ed.), Bergey's Manual of Systematic Bacteriology, $9^{\text {th }}$ Edition. Williams \& Wilkins, Baltimore MD.

Skovgaard, N. and Morgen, C.A. (1988): Detection of Listeria spp. in faeces from animals, in feeds and in raw foods of animal origin. Int. J. Food Microbiol., 6: 229-242.

Tompkin, R.B.; Christiansen, L.N.; Shaparis, A.B.; Baker, R.L and Schroeder, J.M. (1992): Control of Listeria monocytogenes in processed meats. Food Australia, 44: 370-376.

Uyttendaele, M.; Neyts, K.D.; Lips, M.R. and Debevere, J.M. (1997): Incidence of Listeria monocytogenes in poultry and poultry products obtained from Belgian and French abattoirs. Food Microbiol., 14: 339-345.

Uyttendaele, M.; Troy, P.D. and Debevere, J. (1999): Incidence of Listeria monocytogenes in different types of meat products on the Belgian retail market. Int. J. Food Microbiol., 53: 75-80.

Walker, S.F.; Archer, P. and Banks, J.G. (1990): Growth of Listeria monocytogenes at refrigeration temperatures. J. Appl. Bacteriol., 63: 20-23.

Walsh, D.; Duffy, G.; Sheridan, J.J.; Blair, I.S. and McDowell, D.A. (1998): Comparison of selective and non-selective media for the isolation of Listeria species from retail foods. J. Food Safety, 18: 85-89.

Wong, A.C. (1998): Biofilms in food processing environments. J. Dairy Sci., 81: 2765-2770.

Yucel, N.; Cltak, S. and Onder, M. (2005): Prevalence and antibiotic resistance of Listeria species in meat products in Ankara, Turkey. Food Microbiology, 22: 241-245. 